\title{
INTER-FUEL COMPETITION IN ELECTRIC POWER GENERATION: COAL OR NATURAL GAS
}

\author{
D.Gordeev
}

One of the most disputable aspects of Russia's energy markets reform is the feasibility of achieving grid parity between different energy sources, of their socalled inter-fuel competition level indices. Thus, in particular, one of the possible future components of the Russian market for natural gas can be the inter-fuel competition level reached by natural gas and coal in electric power generation. The results of a simplified analysis of current electric energy generation costs demonstrate that at present, natural gas has a huge competitive advantage over coal in electric power generation. At the same time, medium-term moderate growth of prices of natural gas in the domestic market will not result in a switchover, by electric power producers, from natural gas to coal.

Humanity's needs for energy sources vary over time. A change in the demand for a specific primary energy source may be caused by many factors, for example the behavior of prices for energy carriers, changes in analysis, changed technologies, and restrictions introduced within the framework of environmental protection legislation stipulating pollution prevention. As a rule, price parity, or the inter-fuel competition level, is reached when the per unit costs of effective energy production on the basis of different primary power sources become equal. If this condition is not complied with, the primary energy source that generates useful energy at a lower unit-cost will become more preferable, or, in other words, more competitive. Natural gas and coal have been traditionally competing in the heating industry and electric power generation; however, an analysis of current world prices for primary energy sources has revealed that at present there is no inter-fuel competitive parity on a global scale (Table 1) $)^{1}$. According to available statistics, in 2015 the natural gas to coal per unit price ratio in energy production varied from 1.1 to 1.6 , and for Russia, in 2015, this ratio on the average amounted to $1.8^{2}$. This means that the relative levels of natural gas and coal prices in Russia's domestic market are not the same as those observed on the international exchanges, i.e., coal in the domestic market is even more competitive than natural gas, compared to the situation in the foreign market (in foreign markets, the per unit cost of power generated by natural gas is 1.6 times higher than that generated by coal, while in the domestic market it is 1.8 times higher).

Currently the expert community is almost unanimous in believing that the regulated prices of natural gas in Russia are too low, because they do not reflect the real production and transportation costs of natural gas supplied to the consumer regions ${ }^{3}$. In this connection, the necessity to raise the price of natural

1 The reasons why the inter-fuel competition levels can be unachievable are explained later in the text.

2 The authors' calculations are based on the average prices for some types of products purchased by organizations across the Russian Federation in 2012-2015. See Rosstat, http:// www.gks.ru

3 See, for example, D. Gordeev, G. Idrisov, E. Karpel. Theory and practice for natural gas pricing in Russia. Issues of economics (in Russian), 2015, No 1, pp. 80-102; D.G. Tarr, P.D. Thomson. 
PER UNIT COST OF ENERGY GENERATED BY DIFFERENT PRIMARY ENERGY SOURCES

\begin{tabular}{|l|c|c|c|c|c|c|}
\hline \multicolumn{1}{|c|}{ Month } & $\begin{array}{c}\text { Price of } \\
\text { natural gas, } \\
\text { Henry Hub, } \\
\text { USD/1000 m3 }\end{array}$ & $\begin{array}{c}\text { Brent, USD } \\
\text { /barrel }\end{array}$ & $\begin{array}{c}\text { Coal, CAPP, } \\
\text { USD/t }\end{array}$ & $\begin{array}{c}\text { Price of } 1 \mathrm{GJ} \text { of } \\
\text { energy gene- } \\
\text { rated by natural } \\
\text { gas, USD }\end{array}$ & $\begin{array}{c}\text { Price of } 1 \mathrm{GJ} \\
\text { of energy } \\
\text { generated } \\
\text { by oil, USD }\end{array}$ & $\begin{array}{c}\text { Price of } 1 \text { GJ of } \\
\text { energy genera- } \\
\text { ted by coal, USD }\end{array}$ \\
\hline January & 106.3 & 48.4 & 51.3 & 2.7 & 7.9 & 1.8 \\
\hline February & 102.0 & 57.9 & 56.3 & 2.6 & 9.4 & 1.9 \\
\hline March & 100.2 & 55.8 & 58.6 & 2.6 & 9.1 & 2.0 \\
\hline April & 92.4 & 59.4 & 54.5 & 2.4 & 9.7 & 1.9 \\
\hline May & 101.7 & 64.6 & 51.7 & 2.6 & 10.5 & 1.8 \\
\hline June & 99.2 & 62.4 & 46.2 & 2.5 & 10.1 & 1.6 \\
\hline July & 101.3 & 55.9 & 46.3 & 2.6 & 9.1 & 1.6 \\
\hline August & 98.8 & 47.0 & 47.3 & 2.5 & 7.6 & 1.6 \\
\hline September & 94.9 & 47.2 & 46.9 & 2.4 & 7.7 & 1.6 \\
\hline October & 83.1 & 48.1 & 46.3 & 2.1 & 7.8 & 1.6 \\
\hline November & 74.5 & 44.4 & 46.0 & 1.9 & 7.2 & 1.6 \\
\hline December & 68.7 & 37.7 & 47.4 & 1.8 & 6.1 & 1.6 \\
\hline January & 81.3 & 30.8 & 47.7 & 2.1 & 5.0 & \\
\hline 2016 & & & & & & \\
\hline
\end{tabular}

Source: own calculation based on statistics released by IEA and Infomine:: EIA, https://www.eia.gov/; Infomine, http://www.infomine.com/.

gas has frequently been substantiated by arguments that are rather dubious from the point of view of theory of economics - that prices must be raised in order to achieve equal rates of return on the supplies on the domestic and foreign markets (net back pricing) ${ }^{1}$; that prices must be raised so as to eliminate cross-subsidization ${ }^{2}$; or that price must be raised in order to decrease the share of natural gas in the overall energy balance, etc. The necessity to achieve an inter-fuel competition level is also one of these arguments.

The idea that the price of natural gas must be increased in order to prompt inter-fuel competition between natural gas and coal was put forth in 2003 by PJSC Gazprom ${ }^{3}$. In addition to natural gas producers, its higher prices are also demanded by coal companies, on the grounds that at the current ratio of prices of these two energy sources they are not competitive.

The key approach to achieving inter-fuel competition relies on the estimated per unit costs of converting different primary sources of energy into useful energy. The oversimplified argumentation that is sometimes applied in such estimations goes as follows: if, say, the combustion of $1 \mathrm{~kg}$ of anthracite and 1 cubic $\mathrm{m}$ of natural gas will produce heat $29.3 \mathrm{MJ}$ and $39.8 \mathrm{MJ}$ respectively of energy dissipated as heat ${ }^{4}$, the value of natural gas should be $45 \%$ higher.

The merits of dual pricing of Russian natural gas // The World Economy, 2004, vol. 27, Issue 8, pp. 1173-1194.

1 Tarr and Thomson (ibid.) demonstrate that the absence of grid parity between the natural gas supplies in the domestic and foreign markets is beneficial for Russia in terms of public wealth boost: domestic prices must be below the European prices, less export duties and export costs. 2 Gordeev et al. (ibid.) shows that, due to the existence of different cross-subsidization schemes, prices are indeed too low in some RF subjects; but in others, they are too high.

3 Roundtable Prospects for the Oil and Gas Sector Development in Russia and the CIS, presentation by Head of the Economic Expertise and Pricing Department of OJSC Gazprom Elena Karpel, http://www.gazprom.ru/press/news/2003/september/article54564/

4 See engineering reference portal at http://www.dpva.info/ and information portal at www.calc.ru 
However, is should also be noted that this simple equation does not take into account some very significant factors, such as:

- different energy conversion efficiency parameters of the technologies applied to different fuel types ${ }^{1}$;

- the necessary investment costs (which may differ manifold per $1 \mathrm{~kW}$ of power) and the differences in operating costs for each technology;

- the effects of political decisions on the final costs incurred by electric energy producers (for example, restrictions on the use of coal in electric power engineering, tax levied on greenhouse gas emission, promotion of renewable energy sources, enforced technological standards, etc. $)^{2}$.

In addition to the purely economic factors that determine the choice, by investors, of a particular type of technology, there exist many other technical features that account for the differences between thermal power stations (TPS) fired by coal and by natural gas. Among all these, we may point to the following three main parameters:

- base and optimal load capacity;

- speed of start up and shut down;

- cycling speed.

The currently running and prospective TPSs fired by natural gas are better, by all the three parameters, from those fired by coal. Thus, for example, in Australia it takes from 8 to 48 hours to start a boiler furnace in a coal-fired TPS, while in a TPS fired by natural gas the start-up process takes less than an hour ${ }^{3}$. In the USA, coal-fired TPSs increase their capacity load 5-8 times slower that TPS fired by natural gas (about $3 \mathrm{MW} / \mathrm{min}$ vs. $15-25 \mathrm{MW} / \mathrm{min})^{4}$. In other words, these parameters indeed influence very significantly the competition between natural gas and coal in electric power generation.

Below is our simplified model that estimates the costs of heat conversion into $1 \mathrm{~kW}$ of electric power by Russia's electric power generation capacities for coal and natural gas. As a rule, the total costs of the production of $1 \mathrm{~kW}$ of electricity over a period of one year are modeled as a total costs function of existing and planned capacities ${ }^{5}$.

$$
\mathrm{TC}=\mathrm{C}_{\text {fuel }}+\mathrm{OC}+\mathrm{IC}
$$

where TC is total costs; $\mathrm{C}_{\text {fuel }}$ (fuel costs) is the value of fuels purchased in order to keep the facility running; $O C$ is constant and variable (less fuel costs) operating costs necessary to keep the facility running; IC is the cost of borrowed capital needed to install a facility.

In this connection, we applied the following assumptions in our estimation:

- the average purchasing price of anthracite in Russia in 2013 for industrial consumers was $\mathrm{Rb} 1,512$ per ton ${ }^{6}$;

1 Power generation from coal. Measuring and reporting efficiency performance and $\mathrm{CO} 2$ emissions, IEA, 2010.

2 L. Tuthill. Investment in Electricity Generation Under Emissions Price Uncertainty. The Plant-Type Decision. Oxford institute for energy studies, 2008.

3 Introduction to Australia's energy market. Australian energy market operator, 2010.

4 Gas to coal competition in the U.S. power sector. IEA, 2013.

5 Levelized cost and levelized avoided cost of new generation resources in the annual energy outlook 2015. EIA, see http://www.eia.gov/forecasts/aeo/electricity_generation.cfm 6 Average prices of some types of products purchased by organizations across the Russian Federation in 2012-2015. See Rosstat, http://www.gks.ru 
- the average purchasing price of natural gas in Russia in 2013 for industrial consumers was $\mathrm{Rb} 4,638$ per $1000 \mathrm{~m}^{3(1)}$;

- the per unit heating value of coal is $22.5 \mathrm{GJ} / \mathrm{t}^{2}$;

- the per unit heating value of natural gas is $38.4 \mathrm{GJ} / 100 \mathrm{~m}^{3(3)}$;

- the functional period of a generating capacity is 365 calendar days, with an average load of $80 \%$;

- the cost of borrowed capital is $5 \%$ per annum relative to the amount of investment needed to install the required capacities;

- all the other technological parameters are taken from IEA-ETSAP database ${ }^{4}$.

Table 2 shows the estimated costs of running the existing and planned heat and electric power generation capacities fired by coal and natural gas.

Table 2

THE PER-KW ELECTRIC POWER GENERATION COSTS FOR DIFFERENT TYPES OF POWER PLANTS, RB/ KW

\begin{tabular}{|c|c|c|c|c|c|c|c|}
\hline $\begin{array}{c}\text { Power plant } \\
\text { type* }\end{array}$ & 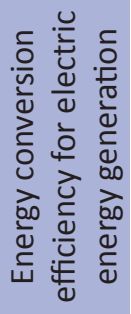 & 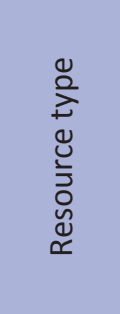 & 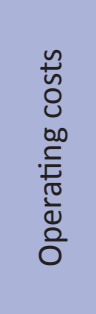 & 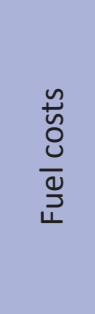 & 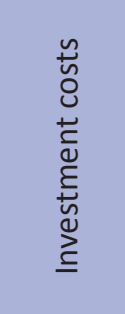 & 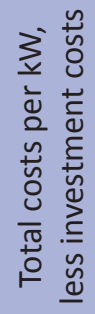 & 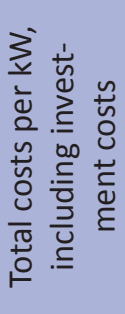 \\
\hline CHPP (FBC) & 0.26 & Coal & 3,341 & 6,492 & 103,415 & 9,833 & 15,004 \\
\hline CHPP (CCGT) & 0.46 & $\begin{array}{l}\text { Natural } \\
\text { gas }\end{array}$ & 1,591 & 6,729 & 41,366 & 8,320 & 10,389 \\
\hline $\begin{array}{l}\text { CHPP (FBC) } \\
\text { in } 2020\end{array}$ & 0.28 & Coal & 3,341 & 6,028 & 95,460 & 9,369 & 14,142 \\
\hline $\begin{array}{l}\text { CHPP (CCGT) } \\
\text { in } 2020\end{array}$ & 0.47 & $\begin{array}{l}\text { Natural } \\
\text { gas }\end{array}$ & 1,527 & 6,586 & 38,184 & 8,114 & 10,023 \\
\hline
\end{tabular}

Source: own calculations based on data released by IEA and Rosstat.

*FBC is a coal-fired TPS where heat and electricity are generated by burning solid fuels in a boiling fluidity bed. CCGT is a TPS fired by natural gas where the production of heat and electricity is achieved by combining a gas turbine and a steam power plant

Given that in Russia's industry all electric power is generated by cogeneration units, it will be feasible to compare only the CHPPs fired by coal and natural gas $^{5}$, leaving aside those power plants that generate electricity alone.

The estimated costs per kW of electricity demonstrate that, from the point of view of economic benefits, it is more profitable to use CHPPs fired by natural gas; it is noteworthy that, while the total costs of the existing types of power plant differ by 15-20\% (the borrowed capital costs are not included in the tariff), the same difference for CHPPs built anew will be about $40-50 \%$. The per unit fuel costs for power plants fired by natural gas are higher than for those fired by coal. So coal (when taken less all other costs) is much more

1 Ibid.

2 U.S. Energy Information and Administration, International Energy Statistics, URL: https:// www.eia.gov/cfapps/ipdbproject/IEDIndex3.cfm?tid=1\&pid=1\&aid=10

3 Ibid.

4 Energy supply technologies, IEA-ETSAP, see www.iea-etsap.org/Energy_Technologies/ Energy_Supply.asp

5 Energy balances of non-OECD countries, IEA, 2015, 580 pp. 
competitive. This can be explained by the low price of coal, which is pushed down, among other things, by the subsidized rail coal transportation rates.

To achieve an inter-fuel pricing parity of natural gas and coal (equalization of the total costs of generating $1 \mathrm{~kW}$ of electricity at new CHPPs), the average price of natural gas should have been increased by $\mathrm{Rb} 3,200$ per 1000 cubic $m$, or by $69 \%$ of its average price in 2013 . However, such a hike in the price of natural gas is unlikely to become acceptable for Russian industry and the government alike over the medium-term period. According to experts, increased prices of natural gas in the domestic market will boost competition between domestic producers through modernization. However, the final price should be formed by the costs incurred in the extraction and transportation of natural gas to the consumer regions ${ }^{1}$. If an inter-fuel competition between natural gas and coal is achieved through the issuance of directives, by imposing constraints and allocating subsidies, this will result in a loss of public wealth, because distorted price signals will conduce to an ineffective use of resources. Besides, if the subsidizing of rail coal transportation rates is to be reduced ${ }^{2}$, the price of natural gas can be expected to surge even higher.

Our simplified analysis of electric energy generation costs demonstrates that at present, coal is not competitive with natural gas as a primary energy source. In view of the expected moderate rise of the prices of natural gas in the domestic market and continued subsidizing the cost of shipping coal by railroad to power plants, the unit costs of electricity generated by natural gas will stay below the corresponding costs for coal. The demand for coal in the domestic market can be boosted only by significantly reducing the investment costs of power plants fired by coal and increasing their energy conversion efficiency. In the export market over the medium- and long-term period, a rising demand for coal will probably be displayed in the main by the developing countries, because the developed ones will be introducing measures designed to bring down their greenhouse gas emission rates ${ }^{3}$.

The global prices of primary energy sources and the choice of best technologies in world practices are strongly influenced by inter-fuel competition. However, we believe that if the price of natural gas in the domestic market is set by a government directive at an inter-fuel competitive level, this will translate into an excessive growth of the manufacturing costs of final product. It is indeed necessary to increase the price of Russian natural gas in a medium- term perspective, but this should occur largely due to the effects of market mechanisms capable of properly balancing the demand and supply only in the natural gas market, and not the achievement of an inter-fuel competition level.

1 See, for example, D. Gordeev, G. Idrisov, E. Karpel. Theory and practice for natural gas pricing in Russia. Issues of economics (in Russian), 2015, No 1, pp. 80-102; I. Dolmatov. Analysis of the impact of prices of energy carriers and natural monopoly tariffs on the competitiveness of Russian companies in the world market. NRU HSE, 2011; T. Fomchenkov. Prices of natural gas must be on the rise. The Russian Gazette, 2013; G. Vygon. What the prices of natural gas in Russia should be like. Gazeta RBC, 2015.

2 Cost optimization by OJSC Russian Railways pushed up the prices of the natural monopoly's services; for further details, see G. Idrisov, E. Ponomareva. The regulation of natural monopolies goes ahead of market development. Russian Economic Developments, 2015, No 8. pp. 64-68.

3 BP Energy Outlook 2016 edition, BP, 2016; World Energy Outlook 2014 Executive Summary, IEA, 2014. 